on African-American steelworkers in Pennsylvania, offered a compelling glimpse of the kinds of histories that can elude the scope of institutional approaches to working-class history. By using some profoundly evocative interviews of former steelworkers, this film captures the emotional pain of black steelworkers whose advancement on the job was blocked by the discriminatory practices of employers. While several workers comment on the indispensability of the union, the film illuminates how employers' racism, combined with the effects of postwar deindustrialization, undermined the social mobility of a whole generation of African-American industrial workers. It was disappointing that this panel was so poorly attended. A collaborative effort by independent filmmakers Tony Buba and Ray Henderson (a former steelworker), who were on hand to lead the session, this film reveals a working-class perspective (rather than a perspective on the working class) that illustrates how seamless the connections between work, family, and community can be.

A general view of the labor studies gathered at this conference indicates that the field has evolved in response to all the talk about crisis. The turn appears to be away from cultural theory and toward the state, the unions, and the conditions of work. After all, methodologically speaking, the linguistic turn precipitated much of the notion of a crisis in the first place. Thus, a more specialized, increasingly pragmatic field of labor history appears to be emerging, a change that could potentially open an interpretive gap between the workplace and the spheres of human experience outside of it.

\title{
Workers and the City: Nineteenth Annual North American Labor History Conference
}

\author{
Nancy Quam-Wickham \\ California State University, Long Beach \\ Lawrence Glickman \\ University of South Carolina \\ Claudia Clark \\ Central Michigan University
}

The nineteenth annual North American Labor History Conference, held in October 1997 at Wayne State University in Detroit, was energized not only by discussions about a new labor history organization but also by excellent panels on the theme of "Workers and the City." (On the former, 
see James Barrett, "A National Association for Working-Class History," ILWCH 53 [Spring 1998]:191-94.) Panels addressed subjects as varied as labor organizing and militancy among urban industrial workers in many settings and time periods, working-class culture and politics in the cities, urban industrial and environmental health, and the contours of working lives and education in urbanizing regions. The conference was distinguished by the breadth of historical scholarship on urban workers presented in these many panels.

In a session on "Contested Streets," historian David Witwer (Lycoming College) and art historians Ellen Wiley Todd (George Mason University) and Melissa Debakis (Kenyon College) examined depictions of early twentieth-century urban American industrial life. Witwer explored how the Teamsters' role in the circulation of goods in urban streets made them central to debates about urban industrial life in this period. Todd contrasted visual and narrative images of the Triangle Shirtwaist strike and fire, while Debakis, in an examination of the sculpture of Abatenia Eberle, showed the problematic nature of the Progressive era's interest in workingclass women. In her comments, historian Ardis Cameron (University of Southern Maine) argued that urban working-class spaces were central to the formation of modern modes of spectacle and spectatorship.

In a panel on "Challenging Categories in Urban/Labor History," Margo Anderson (University of Wisconsin, Milwaukee) and Jan Reiff (University of California, Los Angeles) deconstructed spatial and methodological boundaries in labor history. Anderson argued that early twentieth-century federal agencies artificially divvied up working women's experiences as workers, mothers, and homemakers to the detriment of constructive social policy. Reiff examined the complexities of household space, retail and consumer space, and shifting conceptions of the public sphere at several different moments in the history of Pullman, Illinois. Both papers argued for an integrated analysis that crosses the boundaries of work, home, and community.

A panel that generated a good deal of debate among the audience was "Working-Class Culture in the City," which looked at examples of "knowledge, nature, and adornment" among working people. Tony Michaels (Stanford University) examined the relationship between socialist intellectuals and working people in the Jewish labor movement of New York City. Thomas Zakim (University of Southern California) analyzed the proliferation of working-class gardens in early twentieth-century Los Angeles. Jill Fields (University of Southern California) explored the interrelationships between production and consumption in a study of the International Ladies' Garment Workers' Union's fashion promotions from 1959 to 1963. In his comment, Stephen Norwood (University of Oklahoma) raised questions about the relationship between leaders and the rank and file and suggested that a gendered analysis of all three subjects would enrich these case studies.

Another aspect of urban life, "Working-Class Fellowship and 
Sociability," was examined by Curtis Miner (State Museum of Pennsylvania), Wilson Warren (Indiana State University), and Peter Cole (Georgetown University). Miner looked at ethnic fraternal societies in Johnstown, Pennsylvania. Warren explored the Greater Beneficial Union in Western Pennsylvania. Cole treated attempts at interracial organizing by the Industrial Workers of the World on Philadelphia's waterfront from 1913 to 1927.

A fascinating panel on the politics of race in New York City included papers by Craig Steven Wilder (Williams College), Lisa Phillips (Rutgers University), and Wendell Pritchett (University of Pennsylvania). These papers explored the nature and weaknesses of the postwar interracial liberal coalition. Wilder showed how African Americans and women defense workers were pitted against each other in Brooklyn during World War Two. Phillips examined the relationship between District 65 and civil rights in the postwar years. Comparing the Beth-El Hospital strike of 1962 and the teachers' strike of 1968 , Pritchett pointed to the need to place the latter in a broader historical context.

In the panel "Working for the Gueros: Urban Labor and US Capital in Mexico, 1930-1982," two fine papers examined the relationship between Mexican labor militancy and US corporate organizational regimes. Ken Maffitt (University of California, San Diego) contrasted varying levels of worker militancy among workers at two major electrical manufacturing firms in Mexico (General Electric and IEM), explaining differences in levels of labor militancy in terms of management style, the histories of the two union locals, community development, and the propensity of GE's workers to employ anti-imperialist rhetoric in strikes during the postwar era. Michael Snodgrass (University of Texas) examined the various reasons why Mexican Communists were able to organize successfully among smelter workers in Monterrey-"Mexico's Chicago"-during the 1930s when the Mexican government was ardently anticommunist.

A panel on "Working Class Housing, Political Identity, and Urban Disorder" featured three papers that explored dimensions of working-class community life in twentieth-century San Francisco, Berlin, and the mill towns of Western Pennsylvania. Marie Bolton (University of Paris XII) looked at how the 1906 San Francisco earthquake presented unique opportunities for local politicians and planners to solve longstanding conflicts over the provision for adequate working-class housing, and how clashes over limited resources coupled with public health concerns brought an end to innovative social policy proposals that might have benefited working people. Sace Elder (University of Illinois, Urbana) analyzed the spatial dimensions of class in interwar Berlin neighborhoods, using crime reports to reveal the social and political fragmentation among tenement dwellers in Berlin's industrial suburbs. Steven Burnett (University of Illinois, Urbana) presented a lively paper, arguing that the making of an immigrant urban working class in the United States must be historicized within an environmental context that highlights questions of pollution, filth, and disease. 
A four-panel workshop united scholars from labor studies, medical and labor history, economics, sociology, and public health for an interdisciplinary exploration of the history and current state of workers' health. Presenters discussed the politics of industrial disease definition and protective legislation; many moved beyond workplace health and safety to consider as well class issues in public health, "Red-Green" laborenvironmental conflict and cooperation, and environmental justice concerns about neighborhood pollution and American investment abroad.

A common theme, that pollution affects both sides of the factory wall, united the fields of industrial and environmental health, whose separation serves only to perpetuate myths about jobs versus the environment. Myrna Santiago (University of California, Berkeley) summarized American oil executives' interaction with the Veracruz rain forest and Mexican workers, both of which American ingenuity sought to control during the 1930s. Integrating discussion of unsafe workplaces and unhealthy living spaces, Santiago suggested that class- and race-ranked arrangements led to hierarchies of health, too. Labor militancy in the oil fields was driven by conditions at work and at home. Robert Gordon (Wayne State University) showed how working-class labor organizers and middle-class environmental activists built an alliance during the 1960s and 1970s. He presented the 1973 Oil, Chemical and Atomic Workers' (OCAW) strike against Shell as a moment when this cooperation solidified. Eleven of America's largest environmental organizations supported a strike for increased worker control over factory health and safety conditions, endorsing a boycott and picketing with strikers. Meanwhile, OCAW and other unions lobbied for the Clean Water and Clean Air acts. Perhaps most interesting was Gordon's account of the dissolution of this cooperative spirit. Business strategists consciously manipulated every fissure in the powerful alliance as class conflicts intensified with deindustrialization and Ronald Reagan's onslaught against environmental regulations and organized labor.

This second theme of cross-class alliances was echoed by Alan Derickson (Pennsylvania State University). Returning to the 1968-1969 Black Lung Movement, he argued that middle-class VISTA volunteers brought legalistic tactics and media attention to a militant grassroots movement for worker definition of disease symptoms, qualifying injured miners for compensation.

A third theme was how health ideologies have been shaped by workers and business interests. Elizabeth Toon (University of Pennsylvania) analyzed early twentieth-century insurance company health education programs; Met Life taught customers that "it is cheap to live long," ignoring public health issues in a promotion of particular health habits-and politics. That gender issues shaped ideas about workers' health and safety was demonstrated in a paper by Carolyn Malone (Ball State University) on physicians' perceptions of lead poisoning in nineteenth-century England and Allison Hepler's (University of Maine, Farmington) work on women 
workers' objections to protective policies in American industries during World War Two. Arwen Mohun (University of Delaware) addressed the provocative question of why workers sometimes willingly risked their health, discussing the "calculus of risk" as a social construct shaped by both labor and capital. Patricia Reeve (Boston College) waded in deep theoretical waters, illustrating the "construction of workers' bodies" in nineteenthcentury labor law. Jamie Bronstein (New Mexico State University) compared workers' accounts of accidents with those in the mainstream press: Were injured workers heroes-or victims? Unfortunate-or punished sinners? Illustrations of a Victorian fascination with bloody bodies sparked a comment by Mark Aldrich (Smith College) that the "deconstruction of workers' bodies" has a rather literal meaning in these contexts.

Gerald Markowitz (Graduate Center, City University of New York) and David Rosner (Columbia University School of Public Health) reminded workshop participants that much work remains for those who would challenge business definitions of health and obfuscation of industrial and environmental disease. Updating their work on silicosis, a "disease of the past" according to the professional and business community, they demonstrated that silicosis never vanished and is still claiming lives. New clusters of silicosis have arisen among America's most unorganized and disenfranchised workers in shipyards and refineries in Louisiana, Mississippi, and Texas-revelations that angered workshop participants. The workshops deepened participants' understanding of how business interests control disease definition and health ideologies on "both sides of the factory wall." And yet participants also learned about moments when that domination, while successful, has been at least temporarily challenged. In many panels and workshops, presenters and members of the audience alike agreed that the power of cross-class organizing in the past suggests strategies for workers and citizens today.

\section{Boys and Their Toys? Masculinity, Technology, and Work}

\section{Roger Horowitz}

Hagley Museum and Library

In October 1997, a lively audience of one hundred people gathered at the Hagley Museum and Library to hear papers related to the theme, "Boys and Their Toys? Masculinity, Technology, and Work." The conference emerged out of Hagley's ongoing efforts to encourage scholars engaged in innovative research on gender and society to make use of our printed and manuscript collections on business, work, and technology. 